\title{
Brief History, Pitfalls, and Prospects of Mammalian Spermatogonial Stem Cell Research
}

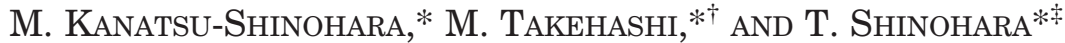 \\ *Department of Molecular Genetics, Graduate School of Medicine, Kyoto University, Kyoto \\ 606-8501, Japan; 'Japan Science and Technology Agency, CREST, Kyoto 606-8501, Japan
}

\begin{abstract}
Spermatogonial stem cells (SSCs) provide the foundation for spermatogenesis. During the last decade, several techniques for the manipulation of this cell type have been developed; as a result, SSCs can now be subjected to long-term in vitro expansion and genetically manipulated for knockout mouse production. These techniques have allowed SSCs to serve as a new target for animal transgenesis, which may provide an alternative to embryonic stem (ES) cells. Furthermore, SSCs may be converted into ES-like cells, demonstrating that the postnatal testis is a source of pluripotent stem cells. These techniques were first established in mice, but they are currently being extended to other animal species. SSC-based technologies will be useful in agriculture and medicine and will also provide valuable opportunities to study SSC biology. The mechanisms of selfrenewal division and differentiation and the regulation of pluripotency in SSCs are now being studied at the molecular level. However, some technical and conceptual pitfalls must be kept in mind when designing and analyzing experimental results. Nevertheless, these advances in SSC research will provide valuable insight into the study of mammalian stem cell systems.
\end{abstract}

Unlike other stem cells, SSCs are distinct in that they can transmit genetic information to the next generation. Although the number of SSCs is very small $\left(2 \times 10^{4}\right.$ to 3 $\times 10^{4}$ cells per mouse testis) (Meistrich and van Beek 1993; de Rooij and Russell 2000), they continue to proliferate throughout life and provide the foundation for spermatogenesis. Although most previous studies of SSCs have involved morphological analyses, the detailed behavior of this rare cell population has been determined precisely. Many basic concepts in SSC behavior were elaborated through these rigorous analyses and have survived the test of time. However, by definition, stem cells are identified only by their ability to undergo selfrenewal, which becomes evident only retrospectively after the production of two daughter cells. The lack of such a functional assay has limited studies on SSCs.

\section{DEVELOPMENT OF A GERM CELL TRANSPLANTATION TECHNIQUE: FUNCTIONAL ANALYSIS OF SSCS}

In 1994, Dr. Ralph Brinster developed a germ cell transplantation technique, in which dissociated donor testicular cells colonized and underwent spermatogenesis in the empty seminiferous tubules of infertile recipient mice (Brinster and Zimmermann 1994). The recipient animals were eventually able to produce offspring. This experiment had two important implications. First, it provided a functional assay for SSCs. Only stem cells can proliferate over the long term and undergo spermatogenesis after transplantation; other differentiated progenitor cells disappear after 35 days, or one cycle of mouse spermatogenesis (Meistrich and van Beek 1993; de Rooij and Russell

†Present address: Laboratory of Pathophysiology and Pharmacotherapeutics, Faculty of Pharmacy, Osaka Ohtani University, Tondabayashi, Osaka 584-8540, Japan.
2000). This technique is somewhat similar to the transplantation assay for hematopoietic stem cells (HSCs), in which stem cells are transplanted into irradiated recipients (Till and McCulloch 1961). Second, this technique allowed for the first manipulation of the male germ line for transgenic animal production. By genetically manipulating SSCs and transplanting these cells into recipient animals, donor stem cells may be used to produce transgenic animals, thereby providing a competitive approach for ES-cell-based mutagenesis.

Since the development of this germ cell transplantation technique, significant progress has been made in several areas of SSC biology; however, the most direct application of this technique was the phenotypic characterization of SSCs. By taking advantage of the concepts of HSC purification, cell surface SSC markers were identified systematically by fractionating and transplanting testicular cells (Shinohara et al. 1999, 2000; Kubota et al. 2003). Second, it became possible to analyze whether specific types of spermatogenic defects were caused by the stem cells or their microenvironment during reciprocal transplantation (Ogawa et al. 2000). Third, xenogeneic spermatogenesis was achieved by interspecific germ cell transplantation. Remarkably, rat spermatogenesis occurred in immunodeficient nude mouse testis, indicating significant flexibility in germ cell-Sertoli cell interactions (Clouthier et al. 1996; Shinohara et al. 2006).

Although germ cell transplantation was very useful in analyzing the biology of SSCs, little progress was made in the genetic manipulation of the male germ line. In fact, the germ cell transplantation technique was originally developed for the genetic manipulation of animal species, an application for which current ES-cell-based gene targeting technique have not been applied. Although ES cells are available for several animal species, only mouse ES cells can produce germ cells, and it has been impossible to produce knockout animals in most species. Although knockout 
animals can be produced by the nuclear transplantation of genetically engineered somatic cells (Denning and Priddle 2003), the limited proliferative potential of somatic cells and inefficient production of offspring has restricted its practical applications. Therefore, it is important to establish a novel method for the production of knockout animals that may be used in a wide range of species. However, although transgenic mice and rats were produced by transfecting SSCs with retroviral vectors, the efficiency was low, and it was not possible to produce knockout animals (Nagano et al. 2001b; Hamra et al. 2002).

\section{THE DEVELOPMENT OF A LONG-TERM CULTURE SYSTEM: GERM-LINE STEM CELLS}

The biggest hurdle for knockout animal production was the inability to culture SSCs. Although SSCs can increase in number in vivo (Kanatsu-Shinohara et al. 2003a; Ogawa et al. 2003), more than $90 \%$ of cultured SSCs undergo apoptosis within 1 week, probably because of a lack of a selfrenewal factor (Orwig et al. 2002). In 2000, glial-cellline-derived neurotrophic factor (GDNF) was found to induce the proliferation of spermatogonia (Meng et al. 2000). Whereas homozygous GDNF knockout mice die perinatally, heterozygous knockout mice exhibit reduced spermatogenesis and eventually become infertile because of germ cell depletion. In contrast, GDNF-transgenic mice possess clumps of undifferentiated spermatogonia, suggesting that GDNF stimulates the self-renewal division of SSCs.

Taking advantage of this finding, our group succeeded in the long-term culture of SSCs in 2003 (KanatsuShinohara et al. 2003b). In the presence of GDNF, SSCs produced uniquely shaped germ cell colonies that were apparently different from ES cell colonies (see Fig. 1a). Unlike ES cells, the cells in the germ cell colony were loosely attached to one another and could be easily dissociated without trypsin. We designated these cells as germline stem (GS) cells. Although GS cells were originally established from neonatal testis, similar cells were subsequently established from adult testis, demonstrating that GS cells can be derived from SSCs at various stages (Kanatsu-Shinohara et al. 2004b; Kubota et al. 2004; Ogawa et al. 2004). Subsequent studies have shown that GS cells are very stable in terms of their germ-line potential and can produce normal fertile offspring even after 2 years of culture (Fig. 1c) (Kanatsu-Shinohara et al. 2005c). Surprisingly, the cultured cells retain a normal karyotype and DNA methylation pattern. This is in contrast to ES cells, which often lose their germ cell potential due to trisomy (Liu et al. 1997; Longo et al. 1997). Similar to ES cells, GS cells can be used to produce transgenic and knockout animals via genetic transduction and drug selection (Kanatsu-Shinohara et al. 2005a, 2006c). However, the efficiency of transgenesis is about $50 \%$, which reflects the fact that the transgene is transmitted to half of the haploid cells. The level of efficiency is five to ten times higher than that achieved by conventional methods using eggs or oocytes (Nagano et al. 2001b). Moreover, the frequency of homologous recombination is comparable to that achieved in ES cells (Kanatsu-Shinohara et al. 2006c). Thus, SSCs may be used as a vehicle for gene targeting.
An unexpected finding that developed from these experiments was the pluripotency of SSCs. Although primordial germ cells (PGCs), the fetal precursors of SSCs, can give rise to ES-like pluripotent cells (Matsui et al. 1992; Resnick et al. 1992), it was thought that germ-line cells are fully committed to the germ line by the middle of gestation and that such ES-like potential is missing from postnatal germ cells (Labosky et al. 1994). In the course of our genetargeting experiments, we detected abnormal colonies in the GS cell culture that subsequently transformed into ESlike cells (Fig. 1b) (Kanatsu-Shinohara et al. 2004b). These cells, referred to as multipotent GS (mGS) cells, differentiate not only into somatic cells, but also into germ cells, and they are capable of producing knockout animals in a manner similar to that of ES cells (Fig. 1d) (Takehashi et al. 2007b). The pluripotency of SSCs was subsequently confirmed by several other groups (Guan et al. 2006; Seandel et al. 2007; Izadyar et al. 2008; Ogawa 2008). However, there are pronounced differences in the phenotypic and functional characteristics of these ES-like cells, which will be the focus of future studies. Although the ori-

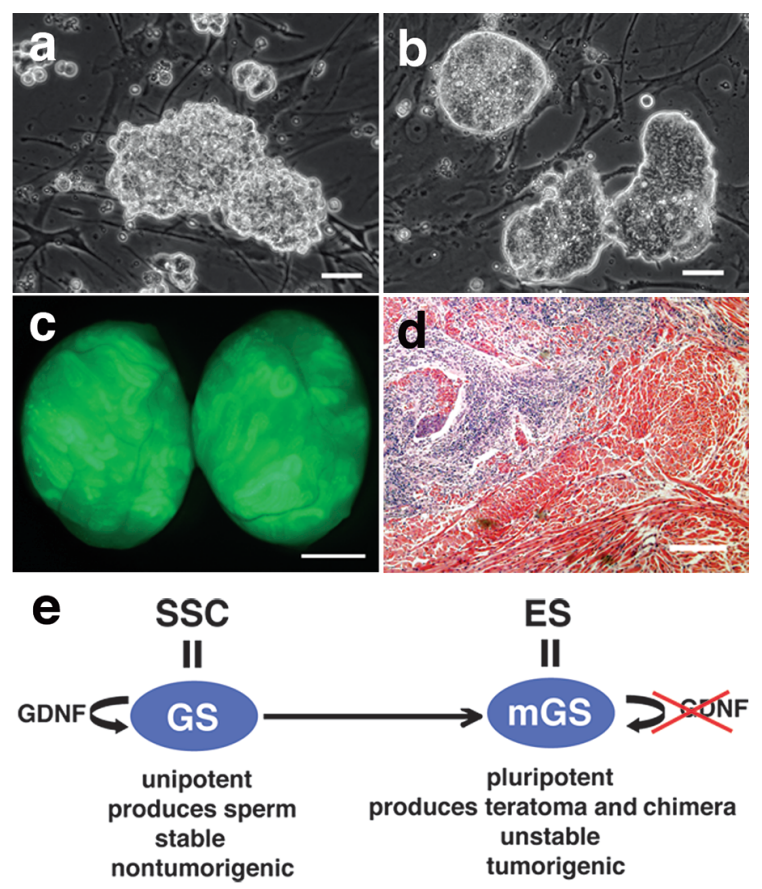

Figure 1. GS and mGS cell characteristics. (a) GS cell culture; (b) mGS cell culture; (c) germ cell colonies formed from GS cells by transplantation into testes. Green fluorescence indicates germ cell colonies from enhanced green fluorescent protein (EGFP)-expressing GS cells. (d) A teratoma produced from mGS cells by subcutaneous transplantation. (e) Schema showing the features of GS cells and mGS cells. GS cells are unipotent and undergo spermatogenesis in the testes. In contrast, mGS cells are pluripotent, like ES cells, and produce teratomas. Although GS cells maintain a normal karyotype, genomic imprinting, and SSC activity during long-term culture, mGS cells are unstable and prone to accumulate genomic and epigenomic abnormalities. A recent report demonstrated that $\mathrm{mGS}$ cells are derived from the conversion of GS cells in culture. Bars, (a,b) $50 \mu \mathrm{m}$; (c) $1 \mathrm{~mm}$; (d) $200 \mu \mathrm{m}$. 
gin of mGS cells is unclear, we recently found that GS cells may be converted directly into mGS cells in vitro (Fig. 1e) (Kanatsu-Shinohara et al. 2008b); however, the process is very rare (mGS cells were established in only 1 of 30 testes), and attempts at increasing the conversion rate have been unsuccessful. Although the activation of Akt enhances ES-like cell formation from PGCs (Kimura et al. 2008), the same treatment only stimulates GS cell selfrenewal (Lee et al. 2007); i.e., it does not enhance their conversion into mGS cells. Therefore, SSCs may be pluripotent, but their conversion into ES-like cells occurs in a manner different from that of PGCs.

\section{PROBLEMS AND PITFALLS IN SSC RESEARCH}

The development of germ cell transplantation and culture techniques has enabled functional analyses and the manipulation of SSCs. No other self-renewing tissues have these advantages; thus, spermatogenesis is an ideal model system for analyzing the regulation of stem cells. However, there are several pitfalls that may confuse the novice in the field.

\section{Use of Functional Analyses to Define SSCs}

The identification of SSC markers has facilitated the identification of SSCs; however, no SSC-specific marker allows the definitive identification of SSCs in situ. For example, not all markers expressed in germ cells from neonatal or immature pup testes should be considered bona fide SSC markers. In fact, only a small fraction of these gonocytes or spermatogonia act as SSCs on the basis of functional criteria (Shinohara et al. 2001). Likewise, the genes that are expressed in primitive germ cell colonies (e.g., chain or network) may not always be appropriate as SSC markers. For example, Neurog3, which is expressed in a chain of spermatogonia (Yoshida et al. 2004), is now known to be more strongly expressed after SSCs start to differentiate (Oatley et al. 2006; Lee et al. 2007). SSC markers should be determined only by prospective isolation and functional transplantation assay.

Although the transplantation assay is the only reliable established method for the identification of SSCs, it should be kept in mind that the criteria for SSCs determined by transplantation are also flexible. For example, the choice of recipient animals can influence the outcome of an experiment. Although approximately $10 \%$ of transplanted As (single) cells undergo spermatogenesis in adult recipients (Nagano et al. 1999), the transplantation of the same cell population into pup recipients results in approximately ten times greater colonization (Shinohara et al. 2001). This result suggests that most of the As cells can colonize pup recipients and that As cells and SSCs, as defined by transplantation assay in the adult recipients, are not equivalent. Hormonal environment in the recipient testis also influences the level of colonization significantly (Ogawa et al. 1999a). Thus, the outcome of a transplantation assay depends on the recipient animal, and great care must be taken to use these definitions when interpreting experimental data.

\section{Not All Cultured Cells Are Bona Fide SSCs}

Another potential source of confusion in SSC research is the distinction between proliferation and self-renewal. For example, SSCs proliferate in response to GDNF in vitro. Without GDNF, no growth occurs, and all of the cells undergo apoptosis within weeks. However, this does not necessarily mean that all cells that respond to GDNF are SSCs. Our analyses have shown that only 1-2\% of GS cells have the potential to colonize seminiferous tubules (Kanatsu-Shinohara et al. 2005c). Therefore, the remaining cells should be defined as differentiated progenitor cells. The distinction between SSCs and progenitor cells is particularly important in the analysis of in vitro data. Because the definition of a stem cell is based on functional criteria, it is impossible to define cultured cells as stem cells simply because they proliferate. For example, imagine an experiment aimed at identifying a molecule that enhances the proliferation of the cultured cells. Even if one of the test molecules efficiently enhances the proliferation of the cultured cells, it does not necessarily mean that it is enhancing self-renewal division. Cultured cells should be assessed for the number of stem cells by transplantation before and after the addition of a test molecule to determine its effect on SSC proliferation. This will determine whether the molecule is involved in self-renewal, proliferation, or apoptosis and cancel its potential effect in colonization.

\section{Definition of a Germ Cell Colony}

Determining the number of colonies in a recipient testis sounds easy, but there are several potential problems. When SSCs are transplanted, donor cells produce colonies of various sizes (Nagano et al. 1999). Because a single SSC produces a single colony (Kanatsu-Shinohara et al. 2006b), this difference in size indicates that the proliferative potential of individual SSCs is variable. The regulatory mechanism underlying this process awaits further study, but it poses a practical problem for the functional analysis of SSCs. In fact, it is impossible to count all of the blue cell clusters in many germ cell transplantation experiments; thus, specific criteria to define a germ cell colony must be set to estimate the number of SSCs in a transplanted cell population. In our work, we have slightly modified the criterion of Nagano et al. (1999), and a cluster of germ cells are defined as a colony when it is at least $0.1 \mathrm{~mm}$ in length and occupies the entire circumference of the seminiferous tubule.

Conversely, individual stem cells may not produce single colonies under other experimental situations. The clonal origin of a germ cell colony may be confirmed only via transplantation experiments and cannot be applied to other cases. For example, when SSCs are labeled in situ (Kanatsu-Shinohara et al. 2004a), the germ cell colonies are generally smaller and have a morphology different from those that develop after germ cell transplantation, which indicates that germ cell colony formation has different kinetics during normal spermatogenesis. In such cases, each colony is not necessarily derived from a single stem cell. It is possible that several clusters of SSCs 
may reside in a niche and only appear to form a single colony; however, no study has addressed this point.

\section{Technical Problems}

A well-known problem in SSC research is transplantation-induced inflammation. Recipient testes often suffer severe inflammation starting several weeks after transplantation. Inflammation occurs most frequently in adult recipients and is rarely observed in immature pup testes (T. Shinohara, unpubl.). The mechanism underlying this response has not been clarified; however, trypan blue may be a causative factor ( $\mathrm{K}$. Jahnukainen, pers. comm.). Trypan blue is very useful for examining the success of microinjection and is often used in germ cell transplantation. However, it is advisable to avoid using trypan blue if signs of inflammation are observed after transplantation.

Another relatively frequent problem is the failure to initiate and maintain GS cells. The initiation of GS cell culture is somewhat tricky because they usually divide very slowly in vivo. These cells are probably unable to proliferate quickly when they are placed in culture. Instead, somatic cells often grow faster in vitro to overcome GS cell growth. This problem can be alleviated, in part, by reducing the serum concentration and increasing the GDNF concentration. The growth of somatic cells is effectively blocked by reducing the serum concentration without disturbing GS cell growth. However, SSCs cannot grow in the complete absence of serum at present. Although two different serumfree culture systems were reported (Kubota et al. 2004; Kanatsu-Shinohara et al. 2005b), the culture was maintained using serum to stop trypsin reaction at each passage in one study (Kubota and Brinster 2008). Moreover, we have not been able to use the serum-free medium to culture GS cells under feeder-free conditions using laminin or suspension cultures (Kanatsu-Shinohara et al. 2005b, 2006a), suggesting that a residual amount of serum included with the feeder cells may promote GS cell propagation. In contrast, low concentrations of GDNF are detrimental to GS cell culture; GS cells do not increase in number in the absence of GDNF.

The culture of GS cells may be initiated from both neonatal and adult testes (Kanatsu-Shinohara et al. 2003b, 2004b; Kubota et al. 2004; Ogawa et al. 2004). Immature testes are useful because the germ cell/somatic cell ratio is relatively high, and germ cells are easily separated from somatic cells based on their differential ability to attach to a gelatin-coated dish. In contrast, it is a prerequisite to purify SSCs from adult testes because only $0.02-0.03 \%$ of the cells are stem cells. In both cases, it is advisable to remove as many somatic cells as possible.

Finally, unlike ES cells, GS cells do not grow robustly and their genetic manipulation is still difficult. For example, because the proliferation of GS cells is influenced by their density, clonal expansion from a single transfected GS cell requires mixing with nontransfected cells to maintain proliferation at low densities following drug selection (Kanatsu-Shinohara et al. 2005a). In addition, although the genetic manipulation of GS cells offers the possibility of examining the function of specific genes in SSCs, care must be taken to confirm that the manipulation will not
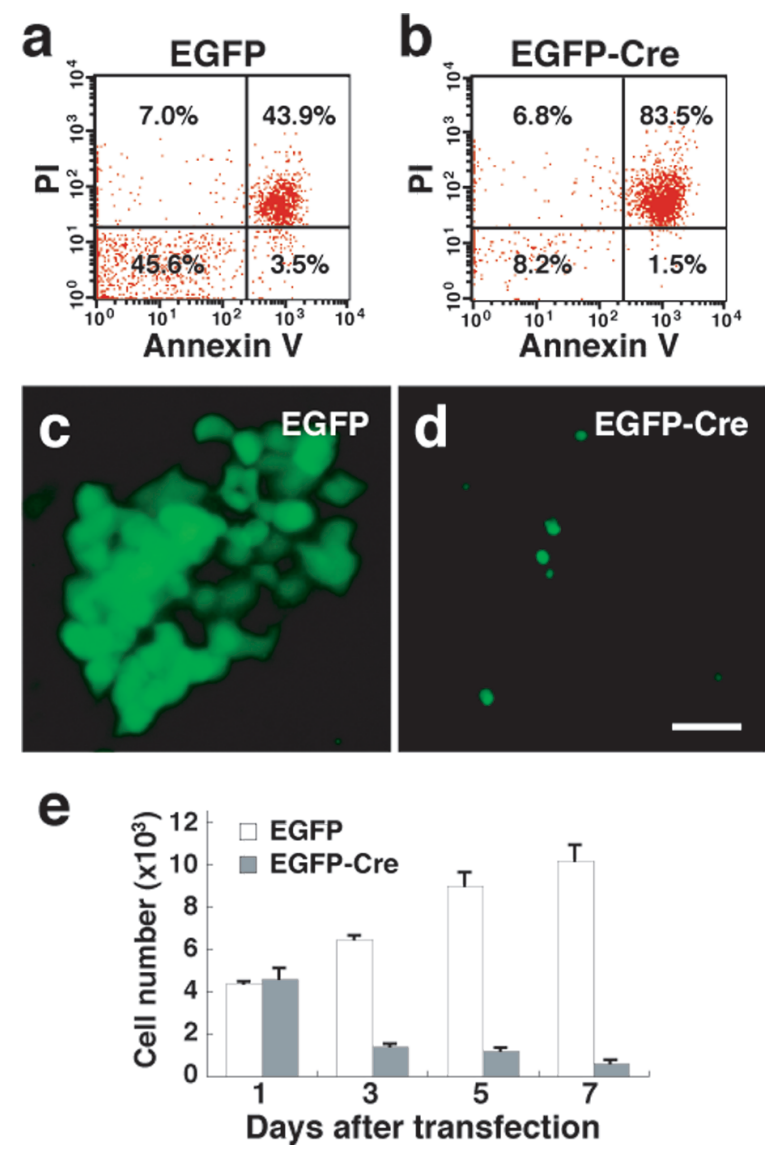

Figure 2. Toxic effects of the overexpression of Cre in GS cells. $(a, b)$ GS cells were transfected with a vector expressing enhanced green fluorescent protein (EGFP, control) $(a)$ or an EGFP-Cre fusion $(b)$ under control of the CAG promoter. To detect cells that were dead or undergoing apoptosis, the cells were stained with annexin V and propidium iodide (PI) after 24 hours and analyzed by flow cytometry. Widespread cell death in response to Cre overexpression was observed. $(c, d)$ Growth of a GS cell colony 9 days after transfection of the EGFP (c) or EGFP-Cre $(d)$ transgene. GS cell colony growth was suppressed when EGFP-Cre was overexpressed in GS cells. Similar results were obtained following the overexpression of a nonfusion Cre transgene by lipofection, electroporation, and retroviral infection. (e) GS cell survival after transfection. GS cells $\left(2.5 \times 10^{5}\right.$ cells) were transfected with the plasmids, and the number of EGFP-expressing germ cells was determined at 1, 3, 5, and 7 days after transfection. The values are the mean \pm S.E.M. $(n=3)$. Bar, $50 \mu \mathrm{m}$ for both $c$ and $d$.

have a toxic effect on the GS cells. We found that GS cells are extremely responsive to Cre expression and that stable Cre expression results in apoptosis (Fig. 2). However, this problem was overcome by using an adenovirus that can transiently express Cre in GS cells (Takehashi et al. 2007a). These technical limitations must be considered when designing experiments using GS cells.

\section{PERSPECTIVES IN SSC RESEARCH}

The transplantation and culture techniques described above were originally developed in mice. However, EScell-based technologies are already available for mouse 
mutagenesis, in which more than $70 \%$ of the total genes are mutated. Therefore, the real value of SSCs lies in their ability to induce mutagenesis in other animal species in which ES-cell-based techniques are not applicable. The use of SSCs has several advantages over conventional methods based on eggs/oocytes. First, GS cells are established from postnatal testes, whereas ES cells are derived from embryos. Unlike mice, most animals do not ovulate large numbers of oocytes and they require a long period of time to reach sexual maturity. These factors limit the genetic manipulation of such animal species. Therefore, GS cell technology has an advantage in many animal species that produce small numbers of offspring. Second, GS cells have very stable genetic and epigenetic properties, probably reflecting the features of SSCs as committed stem cells. This is in contrast to ES cells. Because they are uncommitted to a specific lineage, ES cells can easily differentiate into other lineages, but they may lose their germ-line potential. Therefore, we have good reason to think that GS cells will become a target for mutagenesis in many animal species.

Following its development in 1994, germ cell transplantation has been applied to several animal species, including rats, pigs, bulls, goats, monkeys, and humans (Jiang and Short 1995; Ogawa et al. 1999b; Schlatt et al. 1999; Brook et al. 2001; Honoramooz et al. 2002, 2003). In contrast, the culture of SSCs is only now being developed. The culture conditions for rat and hamster GS cells have been established (Hamra et al. 2005; Ryu et al. 2005; Kanatsu-Shinohara et al. 2008a). Although these results suggest a promising future for the manipulation of SSCs, their application remains limited because of factors such as low fertility (Brinster and Avarbock 1994; Ogawa et al. 1999a). Outside of rodents, the transplantation of SSCs has been used to produce offspring only in goats (Honoramooz et al. 2003). Although the problem of low fertility was successfully overcome by the transplantion of SSCs into immature pup testes, the same treatment may not be applicable to other animal species because of differences in testicular anatomy and biology. In vitro microinsemination may help in some, but apparently not all, cases of infertility.

GS cell culture techniques should also be improved. Although SSCs from rats and hamsters have been cultured successfully, their growth is significantly slower than that of SSCs from mice, which limits the possibility of genetic manipulation. Because SSCs from many animal species grow efficiently in mouse testis (Dobrinski et al. 1999, 2000; Ogawa et al. 1999b; Nagano et al. 2001a), these germ cells could be cultured under conditions similar to those of mouse GS cells.

\section{CONCLUSIONS}

To solve these problems, two issues must be addressed: the improvement of culture conditions and the establishment of an in vitro differentiation technique for GS cells. First, to improve the culture conditions, efforts to identify additional self-renewal factors and establish complete serum- and feeder-free culture systems should be continued. Given the fact that xenogeneic donor stem cells from several animal species can proliferate in mouse testes, there is no doubt that this will become possible in the near future. Second, although germ cell transplantation has been attempted in large animal species and higher primates, low transplantation efficiency and complicated recipient preparation make it unlikely for practical applications. However, with the development of an in vitro sperm differentiation technique, there will be no need to keep animals for germ cell transplantation. The best-case scenario would be to recover SSCs from a piece of testis for GS cell establishment and direct the cells in vitro for sperm production after necessary genetic maniuplations. Those sperm that develop in vitro would in turn be used to fertilize eggs for transgenic animal production. In this way, there will be no need to maintain numerous males for transgenesis, and such a scheme will make mammalian mutagenesis a reality.

\section{ACKNOWLEDGMENTS}

Financial support for this study was provided by the Ministry of Education, Culture, Sports, Science, and Technology of Japan. This work was also supported by the Genome Network Project and by the Program for Promotion of Fundamental Studies in Health Sciences of the National Institute of Biomedical Innovation (NIBIO), and JST, CREST.

\section{REFERENCES}

Brinster, R.L. and Avarbock, M.R. 1994. Germline transmission of donor haplotype following spermatogonial transplantation. Proc. Natl. Acad. Sci. 91: 11303-11307.

Brinster, R.L. and Zimmermann, J.W. 1994. Spermatogenesis following male germ-cell transplantation. Proc. Natl. Acad. Sci. 91: 11298-11302.

Brook, P.F., Radford, J.A., Shalet, S.M., Joyce, A.D., and Gosden, R.G. 2001. Isolation of germ cells from human testicular tissue for low temperature storage and autotransplantation. Fertil. Steril. 75: 269-274.

Clouthier, D.E., Avarbock, M.R., Maika, S.D., Hammer, R.E., and Brinster, R.L. 1996. Rat spermatogenesis in mouse testis. Nature 381: 418-421.

Denning, C. and Priddle, H. 2003. New frontiers in gene targeting and cloning: Success, application and challenges in domestic animals and human embryonic stem cells. Reproduction 126: 1-11.

de Rooij, D.G. and Russell, L.D. 2000. All you wanted to know about spermatogonia but were afraid to ask. J. Androl. 21: 776-798.

Dobrinski, I., Avarbock, M.R., and Brinster, R.L. 1999. Transplantation of germ cells from rabbits and dogs into mouse testes. Biol. Reprod. 61: 1331-1339.

Dobrinski, I., Avarbock, M.R., and Brinster, R.L. 2000. Germ cell transplantation from large domestic animals into mouse testes. Mol. Reprod. Dev. 57: 270-279.

Guan, K., Nayernia, K., Maier, L.S., Wagner, S., Dressel, R., Lee, J.H., Nolte, J., Wolf, F., Li, M., Engel, W., and Hasenfuss, G. 2006. Pluripotency of spermatogonial stem cells from adult mouse testis. Nature 440: 1199-1203.

Honaramooz, A., Megee, S.O., and Dobrinski, I. 2002. Germ cell transplantation in pigs. Biol. Reprod. 66: 21-28.

Honaramooz, A., Behboodi, E., Megee, S.O., Overton, S.A., Galantino-Homer, H., Echelard, Y., and Dobrinski, I. 2003. Fertility and germline transmission of donor haplotype following germ cell transplantation in immunocompetent goats. Biol. Reprod. 69: 1260-1264. 
Hamra, F.K., Chapman, K.M., Nguyen, D.M., WilliamsStephens, A.A., Hammer, R.E., and Garbers, D.L. 2005. Selfrenewal, expansion, and transfection of rat spermatogonial stem cells in culture. Proc. Natl. Acad. Sci. 102: 17430-17435.

Hamra, F.K., Gatlin, J., Chapman, K.M., Grellhesl, D.M., Garcia, J.V., Hammer, R.E., and Garbers, D.L. 2002. Production of transgenic rats by lentiviral transduction of male germ-line stem cells. Proc. Natl. Acad. Sci. 99: 14931-14936.

Izadyar, F., Pau, F., Marh, J., Slepko, N., Wang, T., Gonzalez, R., Ramos, T., Howerton, K., Sayre, C., and Silva, F. 2008. Generation of multipotent cell lines from a distinct population of male germ line stem cells. Reproduction 135: 771-784.

Jiang, F.X. and Short, R.V. 1995. Male germ cell transplantation in rats: Apparent synchronization of spermatogenesis between host and donor seminiferous epithelia. Int. J. Androl. 18: $326-330$.

Kanatsu-Shinohara, M., Toyokuni, S., and Shinohara, T. 2004a. Transgenic mouse produced by retroviral transduction of male germline stem cells in vivo. Biol. Reprod. 71: 1202-1207.

Kanatsu-Shinohara, M., Toyokuni, S., and Shinohara, T. 2005a. Genetic selection of mouse male germline stem cells in vitro: Offspring from single stem cells. Biol. Reprod. 72: 236-240.

Kanatsu-Shinohara, M., Toyokuni, S., Morimoto, T., Matsui, S., Honjo, T., and Shinohara, T. 2003a. Functional assessment of self-renewal activity of male germline stem cells following cytotoxic damage and serial transplantation. Biol. Reprod. 68: 1801-1807.

Kanatsu-Shinohara, M., Miki, H., Inoue, K., Ogonuki, N., Toyokuni, S., Ogura, A., and Shinohara, T. 2005b. Long-term culture of mouse male germline stem cells under serum- or feeder-free conditions. Biol. Reprod. 72: 985-991.

Kanatsu-Shinohara, M., Ogonuki, N., Inoue, K., Miki, H., Ogura, A., Toyokuni, S., and Shinohara, T. 2003b. Long-term proliferation in culture and germline transmission of mouse male germline stem cells. Biol. Reprod. 69: 612-616.

Kanatsu-Shinohara, M., Inoue, K., Lee, J., Miki, H., Ogonuki, N., Toyokuni, S., Ogura, A., and Shinohara, T. 2006a. Anchorage-independent growth of mouse male germline stem cells in vitro. Biol. Reprod. 74: 522-529.

Kanatsu-Shinohara, M., Inoue, K., Miki, H., Ogonuki, N., Takehashi, M., Morimoto, T., Ogura, A., and Shinohara, T. $2006 \mathrm{~b}$. Clonal origin of germ cell colonies after spermatogonial transplantation in mice. Biol. Reprod. 75: 68-74.

Kanatsu-Shinohara, M., Muneto, T., Lee, J., Takenaka, M., Chuma, S., Nakatsuji, N., Horiuchi T., and Shinohara, T. 2008a. Long-term culture of male germline stem cells from hamster testes. Biol. Reprod. 78: 611-617.

Kanatsu-Shinohara, M., Ikawa, M., Takehashi, M., Ogonuki, N., Miki, H., Inoue, K., Kazuki, Y., Lee, J., Toyokuni, S., Oshimura, M., et al. 2006c. Production of knockout mice by random and targeted mutagenesis in spermatogonial stem cells. Proc. Natl. Acad. Sci. 103: 8018-8023.

Kanatsu-Shinohara, M., Inoue, K., Lee, J., Yoshimoto, M., Ogonuki, N., Miki, H., Baba, S., Kato, T., Kazuki, Y., Toyokuni, S., et al. 2004b. Generation of pluripotent stem cells from neonatal mouse testis. Cell 119: 1001-1012.

Kanatsu-Shinohara, M., Lee, J., Inoue, K., Ogonuki, N., Miki, H., Toyokuni, S., Ikawa, M., Nakamura, T., Ogura, A., and Shinohara, T. 2008b. Pluripotency of a single spermatogonial stem cell in mice. Biol. Reprod. 78: 681-687.

Kanatsu-Shinohara, M., Ogonuki, N., Iwano, T., Lee, J., Kazuki, Y., Inoue, K., Miki, H., Takehashi, M., Toyokuni, S., Oshimura, M., et al. $2005 \mathrm{c}$. Genetic and epigenetic properties of mouse male germline stem cells during long-term culture. Development 132: 4155-4163.

Kimura, T., Tomooka, M., Yamano, N., Murayama, K., Matoba, S., Umehara, H., Kanai, Y., and Nakano, T. 2008. AKT signaling promotes derivation of embryonic germ cells from primordial germ cells. Development 135: 869-879.

Kubota, H. and Brinster, R.L. 2008. Culture of rodent spermatogonial stem cells, male germline stem cells of the postnatal animal. Methods Cell Biol. 86: 59-84.

Kubota, H., Avarbock, M.R., and Brinster, R.L. 2003. Spermatogonial stem cells share some, but not all, phenotypic and functional characteristics with other stem cells. Proc. Natl. Acad. Sci. 100: 6487-6492.

Kubota, H., Avarbock, M.R., and Brinster, R.L. 2004. Growth factors essential for self-renewal and expansion of mouse spermatogonial stem cells. Proc. Natl. Acad. Sci. 101: 16489 16494.

Labosky, P.A., Barlow, D.P., and Hogan, B.L.M. 1994. Mouse embryonic germ (EG) cell lines: Transmission through the germline and differences in the methylation imprint of insulin-like growth factor 2 receptor $(\operatorname{Ig} f 2 r)$ gene compared with embryonic stem (ES) cell lines. Development 120: 3197-3204.

Lee, J., Kanatsu-Shinohara, M., Inoue, K., Ogonuki, N., Miki, H., Toyokuni, S., Kimura, T., Nakano, T., Ogura, A., and Shinohara, T. 2007. Akt mediates self-renewal division of mouse spermatogonial stem cells. Development 134: 18531859.

Liu, X., Wu, H., Loring, J., Hormuzdi, S., Disteche, C.M., Bornstein, P., and Jaenisch, R. 1997. Trisomy eight in ES cells is a common potential problem in gene targeting and interferes with germ line transmission. Dev. Dyn. 209: 85-91.

Longo, L., Bygrave, A., Grosveld, F.G., and Pandolfi, P.P. 1997. The chromosome make-up of mouse embryonic stem cells is predictive of somatic and germ cell chimaerism. Transgenic Res. 6: 321-328.

Matsui, Y., Zsebo, K., and Hogan, B.L. 1992. Derivation of pluripotential embryonic stem cells from murine primordial germ cells in culture. Cell 70: 841-847.

Meistrich, M.L. and van Beek, M.E.A.B. 1993. Spermatogonial stem cells. In Cell and molecular biology of the testis (ed. C. Desjardins and L.L. Ewing), pp. 266-295. Oxford University Press, New York.

Meng, X., Lindahl, M., Hyvönen, M.E., Parvinen, M., de Rooij, D.G., Hess, M.W., Raatikainen-Ahokas, A., Sainio, K., Rauvala, H., Lakso, M., et al. 2000. Regulation of cell fate decision of undifferentiated spermatogonia by GDNF. Science 287: 1489-1493.

Nagano, M., Avarbock, M.R., and Brinster, R.L. 1999. Pattern and kinetics of mouse donor spermatogonial stem cell colonization in recipient testes. Biol. Reprod. 60: 1429-1436.

Nagano, M., McCarrey, J.R., and Brinster, R.L. 2001a. Primate spermatogonial stem cells colonize mouse testes. Biol. Reprod. 64: 1409-1416.

Nagano, M., Brinster, C.J., Orwig, K.E., Ryu, B.Y., Avarbock, M.R., and Brinster, R.L. 2001b. Transgenic mice produced by retroviral transduction of male germ-line stem cells. Proc. Natl. Acad. Sci. 98: 13090-13095.

Oatley, J.M., Avarbock, M.R., Telaranta, A.I., Fearon, D.T., and Brinster, R.L. 2006. Identifying genes important for spermatogonial stem cell self-renewal and survival. Proc. Natl. Acad. Sci. 103: 9524-9529.

Ogawa, T. 2008. Reproductive stem cell research and its application to urology. Int. J. Urol. 15: 121-127.

Ogawa, T., Dobrinski, I., and Brinster, R.L. 1999a. Recipient preparation is critical for spermatogonial transplantation in the rat. Tissue Cell 31: 461-472.

Ogawa, T., Dobrinski, I., Avarbock, M.R., and Brinster, R.L. 1999b. Xenogeneic spermatogenesis following transplantation of hamster germ cells to mouse testes. Biol. Reprod. 60: 515-521.

Ogawa, T., Dobrinski, I., Avarbock, M.R., and Brinster, R.L. 2000. Transplantation of male germ line stem cells restores fertility in infertile mice. Nat. Med. 6: 29-34.

Ogawa, T., Ohmura, M., Yumura, Y., Sawada, H., and Kubota, Y. 2003. Expansion of murine spermatogonial stem cells through serial transplantation. Biol. Reprod. 68: 316-322.

Ogawa, T., Ohmura, M., Tamura, Y., Kita, K., Ohbo, K., Suda, T., and Kubota, Y. 2004. Derivation and morphological characterization of mouse spermatogonial stem cell lines. Arch. Histol. Cytol. 67: 307-314.

Orwig, K.E., Avarbock, M.R., and Brinster, R.L. 2002. Retrovirus-mediated modification of male germline stem cells in rats. Biol. Reprod. 67: 874-879.

Resnick, J.L., Bixler, L.S., Cheng, L., and Donovan, P.J. 1992. 
Long-term proliferation of mouse primordial germ cells in culture. Nature 359: 550-551.

Ryu, B.Y., Kubota, H., Avarbock, M.R., and Brinster, R.L. 2005. Conservation of spermatogonial stem cell self-renewal signaling between mouse and rat. Proc. Natl. Acad. Sci. 102: 14302-14307.

Schlatt, S., Rosiepen, G., Weinbauer, G.F., Rolf, C., Brook, P.F., and Nieschlag E. 1999. Germ cell transfer into rat, bovine, monkey and human testes. Hum. Reprod. 14: 144-150.

Seandel, M., James, D., Shmelkov, S.V., Falciatori, I., Kim, J., Chavala, S., Scherr, D.S., Zhang, F., Torres, R., Gale, N.W., et al. 2007. Generation of functional multipotent adult stem cells from GPR $125^{+}$germline progenitors. Nature 449: 346-350.

Shinohara, T., Avarbock, M.R., and Brinster, R.L. 1999. $\beta 1$ - and $\alpha 6$-integrin are surface markers on mouse spermatogonial stem cells. Proc. Natl. Acad. Sci. 96: 5504-5509.

Shinohara, T., Orwig, K.E., Avarbock, M.R., and Brinster, R.L. 2000. Spermatogonial stem cell enrichment by multiparameter selection of mouse testis cells. Proc. Natl. Acad. Sci. 97: $8346-8351$.

Shinohara, T., Orwig, K.E., Avarbock, M.R., and Brinster, R.L. 2001. Remodeling of the postnatal mouse testis is accompa- nied by dramatic changes in stem cell number and niche accessibility. Proc. Natl. Acad. Sci. 98: 6186-6191.

Shinohara, T., Kato, M., Takehashi, M., Lee, J., Chuma, S., Nakatsuji, N., Kanatsu-Shinohara, M., and Hirabayashi, M. 2006. Rats produced by interspecies spermatogonial transplantation in mice and in vitro microinsemination. Proc. Natl. Acad. Sci. 103: 13624-13628.

Takehashi, M., Kanatsu-Shinohara, M., Inoue, K., Ogonuki, N., Miki, H., Toyokuni, S., Ogura, A., and Shinohara, T. 2007a. Adenovirus-mediated gene delivery into mouse spermatogonial stem cells. Proc. Natl. Acad. Sci. 104: 2596-2601.

Takehashi, M., Kanatsu-Shinohara, M., Miki, H., Lee, J., Kazuki, Y., Inoue, K., Ogonuki, N., Toyokuni, S., Oshimura, M., Ogura, A., and Shinohara, T. 2007b. Production of knockout mice by gene targeting in multipotent germline stem cells. Dev. Biol. 312: 344-352.

Till, J.E. and McCulloch, E.A. 1961. A direct measurement of the radiation sensitivity of normal mouse bone marrow cells. Radiat. Res. 14: 213-222.

Yoshida, S., Takakura, A., Ohbo, K., Abe, K., Wakabayashi, J., Yamamoto, M., Suda, T., and Nabeshima, Y. 2004. Neurogenin3 delineates the earliest stages of spermatogenesis in the mouse testis. Dev. Biol. 269: 447-458. 


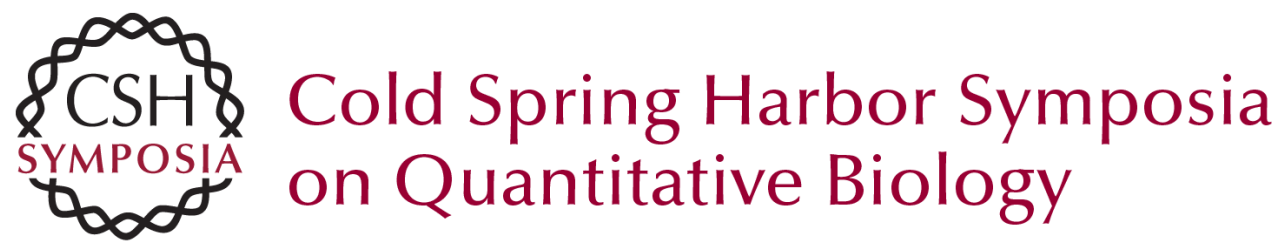

\section{Brief History, Pitfalls, and Prospects of Mammalian Spermatogonial Stem Cell Research}

M. Kanatsu-Shinohara, M. Takehashi and T. Shinohara

Cold Spring Harb Symp Quant Biol 2008 73: 17-23 originally published online November 6, 2008 Access the most recent version at doi:10.1101/sqb.2008.73.033

References This article cites 60 articles, 22 of which can be accessed free at: http://symposium.cshlp.org/content/73/17.full.html\#ref-list-1

\section{License}

Email Alerting Receive free email alerts when new articles cite this article - sign up in the box at the Service top right corner of the article or click here. 